\title{
neofilolog
}

Czasopismo Polskiego Towarzystwa Neofilologicznego

ISSN 1429-2173, elSSN 2545-3971, 2020, NR 55/1, 125-144

http://dx.doi.org/10.14746/n.2020.55.1.8

http://poltowneo.org/

Olga Aleksandrowska

Uniwersytet Gdański

https://orcid.org/0000-0002-3722-9568

olga.aleksandrowska@ug.edu.pl

Danuta Stanulewicz

Uniwersytet Gdański

https://orcid.org/0000-0003-1792-3883

danuta.stanulewicz@ug.edu.pl

\section{Internetowa platforma do nauki języków Duolingo - opinie użytkowników}

\section{The online language learning platform Duolingo: Users' opinions}

A recent increase in the introduction and integration of information and communication technologies in education has prompted researchers to investigate the functioning and effectiveness of various digital tools. In the first part of the article, the authors present the benefits of using online platforms in language learning, with special focus on Duolingo. The second part describes the major assumptions, course design and language tasks offered by the platform. The final part concentrates on the results of a small-scale study in the form of interviews, conducted with 32 Duolingo users.

Keywords: language learning platforms, Duolingo, self-assessment, English as the language of instruction, gamification

Słowa kluczowe: internetowe platformy do nauki języków, Duolingo, samoocena, angielski jako język nauczania, grywalizacja 


\section{Wprowadzenie}

Osoba pragnąca nauczyć się języka w systemie pozaszkolnym lub kontynuować naukę języka ma do dyspozycji bogatą ofertę darmowych lub płatnych platform edukacyjnych, aplikacji mobilnych oraz kursów e-learningowych. Narzędzia te wydają się nieocenioną pomocą we wspieraniu poznawania języków obcych ze względu na wiele korzyści, które przynoszą. Po pierwsze, wiele z nich oferuje bezpłatny dostęp do zasobów edukacyjnych, promując ideę równości szans edukacyjnych. M ożliwość nieustannego korzystania z cyfrowych źródeł wspiera także ideę life long learning, a więc edukacji przez całe życie, co sprzyja rozwojowi indywidualnemu jednostki, a także podniesieniu ogólnego poziomu edukacji w społeczeństwie. Ponadto, korzystanie z sieci działającej całą dobę wydłuża czas kontaktu osoby uczącej się z językiem, co może wpłynąć korzystnie na efektywność nauki. „Cyfrowi tubylcy” bez problemu sięgną do rekomendowanych źródeł edukacyjnych, by rozwijać swoje umiejętności językowe.

Kolejna duża zaleta korzystania z technologii informacyjno-komunikacyjnych (TIK) to wielość i różnorodność materiałów i narzędzi przeznaczonych do nauki języków obcych. Przewaga liczebna zasobów cyfrowych nad tradycyjnymi, oferowanymi na przykład w księgarni lub bibliotece, jest zauważalna. Użytkownik sieci ma do dyspozycji niezliczoną liczbę stron internetowych, programów, kursów, platform i aplikacji. Istotne jest także to, że nauka w sieci jest polisensoryczna i interaktywna. Dzięki zastosowaniu m.in. ciekawej grafiki i podcastów, uczący się może efektywniej przyswoić i utrwalić dany materiał edukacyjny.

Następna korzyść wynika z faktu, iż technologie informacyjno-komunikacyjne umożliwiają większą niż tradycyjne formy kształcenia, indywidualizację. Jak podkreśla Szałek (2004), zasada indywidualizacji jest jednym z filarów nauczania zorientowanego na osobę ucznia i czynnikiem w dużej mierze wzmacniającym jego motywację do nauki. Rozwiązania e-learningowe, a więc także platformy glottodydaktyczne, wdrażają ideę takiego zindywidualizowanego nauczania i oferują szereg narzędzi dostosowanych do specyficznych potrzeb uczącego się. Dzięki wspomnianej już bogatej ofercie, osoby różniące się wiekiem, zainteresowaniami, typem motywacji, tempem nauki, poziomem znajomości języka, preferencjami dotyczącymi strategii uczenia się i możliwościami, są w stanie znaleźć dla siebie formę nauki, która będzie dla nich najwygodniejsza lub najkorzystniejsza. Co ciekawe, na personalizacji skorzystają nie tylko uczący się języka o rozwiniętej inteligencji intrapersonalnej, którzy preferują pracę samodzielną, ale też i osoby z dominującą inteligencją interpersonalną, lubiące uczyć się we współpracy z innymi. Narzędzia sieciowe dają bowiem możliwość tworzenia społeczności, grup użytkowników, które mogą ze sobą współpracować, wzajemnie się wspierać, integrować, motywować lub rywalizować ze sobą. Jeszcze inny argument przemawiający 
za wykorzystaniem nowych technologii w nauce języka to oferowany przez wiele narzędzi cyfrowych system grywalizacji, a więc zastosowania mechanizmu gier, który służyć ma do większej mobilizacji, zaangażowania i obudzenia „ducha walki”. Zakłada on, że osoby uczące się języka będą chciały sprawdzać nabywaną wiedzę i umiejętności w formie kwizów, gier, zadań-wyzwań. Elementy grywalizacji pozwalają uczącemu śledzić własne postępy, zawierają informację zwrotną, proponują też system nagradzania, co ma podnieść atrakcyjność nauki języka i wzmocnić motywację.

Wymienione powyżej najważniejsze korzyści wykorzystania różnych form nauki języka obcego w sieci sprawiają, że edukatorzy i badacze przyglądają się funkcjonowaniu i efektywności stosowanych narzędzi TIK (zob. m.in. Krajka, 2007, 2012; M aciaszczyk, 2019; M arczak i Krajka, red. , 2016; Pitura i Sauro, red., 2018; Szerszeń, 2014; Turula i Chojnacka, red. , 2015; Turula, M ikołajewska i Stanulewicz, red., 2015). Również i nas zainteresowało działanie i przydatność internetowych platform oraz aplikacji do nauki języka. W niniejszym artykule chcemy przyjrzeć się jednej z najbardziej popularnych platform oferującej kursy języków obcych, tj. Duolingo. Omówimy pokrótce główne założenia funkcjonowania tej platformy, jej ofertę językową, budowę kursów, a także stosowane typy ćwiczeń. Przedstawimy również wybrane opinie o korzystaniu z niej, pochodzące z wywiadów z jej 32 użytkownikami uczącymi się różnych języków.

\section{Duolingo i inne platformy do nauki języków obcych}

Na rynku edukacyjnym dostępnych jest wiele internetowych platform i aplikacji oferujących kursy do nauki języków. Niektóre z nich zyskują większą popularność niż pozostałe ze względu na swoją funkcjonalność, darmowy dostęp bądź bogatą ofertę kursów. Do platform najczęściej używanych przez internautów należą między innymi:

- Babbel (https://pl.babbel.com/),

- Busuu (http://www.busuu.com/pl),

- Digital Languages (http:// www.digitaldialects.com/ ),

- Duolingo (http://www.duolingo.com),

- eTutor (https://www.etutor.pl/),

- Lang-8 (http://lang-8.com/),

- LingQ (http://www.lingq.com/en/),

- Lingualia (https://www.lingualia.com/),

- Memrise (https://www.memrise.com/),

- Papora (https://www.papora.com/),

- Rosetta Stone (http://www.rosettastone.com). 
Niektóre z tych platform dają możliwość korzystania zaplikacji mobilnych, czyli oprogramowania działającego na urządzeniach przenośnych, na przykład smartfonach czy tabletach. M imo iż platformy oferują zazwyczaj szerszy wybór narzędzi i funkcji niż aplikacje mobilne, to te ostatnie wydają się równie atrakcyjne. Używając ich, można uczyć się bez dostępu do Internetu. Poza tym stanowią one wygodną formę nauki dla osób często podróżujących i pragnących uczyć się języka w różnych miejscach.

Platformy do nauki języków bywają płatne i darmowe. Niektóre z nich oferują zarówno darmowe, jak i płatne kursy, określane jako premium. Znaczna część osób uczących się języków samodzielnie, zwłaszcza uczniowie i studenci, zainteresowana jest korzystaniem z darmowej oferty kursów.

Jedną z platform oferujących bezpłatne kursy jest Duolingo, działająca pod adresem www.duolingo.com ${ }^{1}$. Została ona założona przez Luisa von Ahna i Severina Hackera w roku 2012. Jak dowiadujemy się z wywiadu przeprowadzonego przez Honoratę Zapaśnik z von Ahnem, wychował się on w Gwatemali, w kraju, w którym obserwował spore różnice w dostępie do edukacji. Wraz ze swoim studentem, Hackerem, postanowił więc stworzyć platformę, z której skorzystać będą mogli wszyscy, bez względu na swoją sytuację finansową. Obaj zdecydowali się na stworzenie serwisu do nauki języków z uwagi na ich popularność oraz na ich znaczenie w zdobyciu lepszej pracy. Dla mnie Duolingo jest niesamowite, mówi von Ahn, „bo z nami języka uczą się zarówno Bill Gates, najbogatszy człowiek świata, jak i ci, których nie byłoby stać na kurs. I o to nam chodziło" (Zapaśnik, 2018).

Twórcy Duolingo na stronie internetowej platformy zamieścili tzw. Manifesto, tj. deklarację, w której przedstawiają wizję i misję swojego serwisu. Trzy jej elementy są mocno zaakcentowane: dążenie do spersonalizowanej edukacji, uczenie się poprzez zabawę oraz powszechna dostępność. Dodatkowo fakt, iż platforma nosi nazwę „Duolingo”, wskazuje na istotną rolę, jaką von Ahn i Hacker przypisują koncepcji dwujęzyczności. Kursy przez nich oferowane

\footnotetext{
${ }^{1}$ O platformie Duolingo piszemy bardziej szczegółowo w: Aleksandrowska i Stanulewicz (2019). Poświęcamy tam więcej uwagi m.in. pobudkom, którymi kierowali się twórcy tej platformy (s. 122-123) czy kursom języków używanych przez małe społeczności (s. 125126). Przedstawiamy również przykładowy kurs języka angielskiego dla użytkowników polskiego (s. 127), a także japońskiego dla użytkowników języka angielskiego (s. 129130). W niniejszym artykule zajmujemy się - z innej perspektywy - typami ćwiczeń, jak również zagadnieniami wcześniej pominiętymi, takimi jak informacja zwrotna czy korekta błędów. W pracy z roku 2019 przedstawiłyśmy skrótowo częściowe wyniki badań pilotażowych przeprowadzonych z sześcioma osobami, natomiast tutaj analizujemy wybrane odpowiedzi, które uzyskałyśmy od 32 użytkowników Duolingo.
} 
bowiem są dwujęzyczne. Jeden język staje się językiem nauczania, a drugi językiem nauczanym².

Oferta kursów dla użytkowników języka angielskiego jest najbogatsza: mogą oni wybrać m.in. francuski, hiszpański, japoński, turecki czy też polski (uczy się go 874 tys. użytkowników platformy ${ }^{3}$ ). Za pośrednictwem języka polskiego można uczyć się jedynie angielskiego (z możliwości tej korzysta 1,66 mln użytkowników platformy ${ }^{4}$ ). Tabela 1 przedstawia języki, które można poznać za pomocą Duolingo.

\begin{tabular}{|l|l|}
\hline $\begin{array}{l}\text { Jezzyk } \\
\text { wyjściowy/ } \\
\text { nauczania }\end{array}$ & Języki nauczane (docelowe)* \\
\hline angielski & $\begin{array}{l}\text { hiszpański, francuski, niemiecki, japoński, włoski, koreański, chiński, rosyjski, } \\
\text { portugalski, turecki, niderlandzki, arabski, szwedzki, hindi, grecki, irlandzki, } \\
\text { starovalyriański, polski, norweski (bokmål), hebrajski, łacina (wersja beta), } \\
\text { wietnamski, hawajski, duński, rumuński, czeski, indonezyjski, walijski, klingoń- } \\
\text { ski (wersja beta), suahili, węgierski (wersja beta), ukraiński, nawaho (wersja } \\
\text { beta), esperanto, gaelicki szkocki }\end{array}$ \\
\hline arabski & angielski, francuski, niemiecki, szwedzki; W przygotowaniu: hiszpański \\
\hline bengalski & angielski \\
\hline chiński & $\begin{array}{l}\text { angielski, japoński, koreański, hiszpański, francuski, włoski; W przygotowaniu: } \\
\text { niemiecki }\end{array}$ \\
\hline Czeski & angielski \\
\hline francuski & angielski, hiszpański, włoski, niemiecki, portugalski \\
\hline grecki & angielski \\
\hline hindi & angielski \\
\hline hiszpański & $\begin{array}{l}\text { angielski, francuski, włoski, portugalski, niemiecki, rosyjski, kataloński, espe-- } \\
\text { ranto, guarani, szwedzki (wersja beta) }\end{array}$ \\
\hline indonezyjski & angielski \\
\hline japoński & angielski, chiński (wersja beta) \\
\hline koreański & angielski \\
\hline niderlandzki & Angielski; W przygotowaniu: niemiecki \\
\hline niemiecki & angielski, hiszpański, francuski \\
\hline polski & angielski \\
\hline portugalski & angielski, hiszpański, francuski, włoski, niemiecki, esperanto (wersja beta) \\
\hline pendżabski & W przygotowaniu: angielski \\
\hline rosyjski & angielski, niemiecki, francuski, hiszpański; W przygotowaniu: szwedzki \\
\hline rumuński & angielski \\
\hline tagalog & W przygotowaniu: angielski \\
\hline tajski & angielski \\
\hline
\end{tabular}

2 O roli języka drugiego w opanowaniu następnego języka piszą m.in. Kucharczyk (2018), Orłowska (2015).

${ }^{3}$ Stan na 29.12.2019.

${ }^{4}$ Stan na 29.12.2019. 
Olga Aleksandrowska, Danuta Stanulewicz

\begin{tabular}{|l|l|}
\hline tamilski & W przygotowaniu: angielski \\
\hline telugu & W przygotowaniu: angielski \\
\hline turecki & angielski, niemiecki, rosyjski; W przygotowaniu: francuski \\
\hline ukraiński & angielski \\
\hline węgierski & angielski \\
\hline wietnamski & angielski \\
\hline włoski & angielski, francuski, niemiecki, hiszpański \\
\hline
\end{tabular}

Tabela 1: Kursy językowe oferowane przez Duolingo (stan na 29.12.2019). * Kursy podane są w kolejności popularności wśród użytkowników Duolingo. Oprac. na podst.: https://www.duolingo.com/courses/ [DW 29.12.2019]

Duolingo ma obecnie ponad 300 milionów użytkowników ${ }^{5}$, którzy najchętniej uczą się trzech języków: angielskiego, hiszpańskiego i francuskiego (Settles i in., 2018: 57). Oprócz kursów znajdą oni na platformie m.in. tematyczne fiszki ${ }^{6}$, krótkie opowiadania ${ }^{7}$ i podcasty ${ }^{8}$ do czytania i słuchania, a także dwujęzyczne słowniki ${ }^{9}$. Użytkownicy platformy nie tylko mogą uczyć się na kursach, lecz także brać udział w ich opracowaniu, jak również być moderatorami i uczestnikami dyskusji na forum Duolingo ${ }^{10}$.

\section{Struktura kursów}

Kurs na platformie Duolingo zawiera szereg lekcji zwanych tematami, z których każdy oferuje ćwiczenia na różnych poziomach. Warunkiem przejścia do kolejnej lekcji jest zaliczenie ćwiczeń z tematów poprzednich, choć ta zasada nie dotyczy wszystkich poziomów danego tematu, a jedynie pierwszego. W lekcjach tematy gramatyczne (np. czas teraźniejszy, przyimki, przysłówki, określniki) występują obok pól leksykalnych (np. ubrania, pojęcia abstrakcyjne, sport) i szerszych zagadnień (np. sztuka, polityka) (zob. tabela 2).

Trzeba tu zaznaczyć, że kurs jednego języka może zawierać różną liczbę tematów - w zależności od poziomu językowego osiągniętego przez użytkownika: można tu więc dostrzec deklarowaną w Manifesto personalizację nauczania. Należy też docenić możliwość dopasowania systemu nauki do potrzeb/możliwości uczącego się, który oferuje na przykład wybór stopnia trudności, tempa

\footnotetext{
${ }^{5}$ Duolingo research, https:// research.duolingo.com/ [DW 29.12.2019].

${ }^{6}$ Tinycards, https://tinycards.duolingo.com/ [DW 29.12.2019].

${ }^{7}$ Duolingo stories, https://stories.duolingo.com/ [DW 29.12.2019].

${ }^{8}$ Duolingo podcast, https://podcast.duolingo.com/ [DW 29.12.2019].

${ }^{9} \mathrm{~Np}$. słownik polsko-angielski i angielsko-polski (Polish-English translation) znajduje się pod adresem: https://www.duolingo.com/dictionary/pl [DW 29.12.2019].

${ }^{10}$ Duolingo language forums, https://forum.duolingo.com/ [DW 16.01.2019].
} 
pracy, liczby powtórzeń danego zagadnienia, czasu i długości trwania lekcji (zob. Szatek, 2004: 155-156) w kontekście indywidualizacji nauczania. Ponadto platforma ewoluuje, zmieniając formaty kursów, przy czym dostosowuje do nich kursy wcześniej rozpoczęte. W związku z tym użytkownik może od czasu do czasu zauważyć, że jego kurs nie tylko został inaczej „zorganizowany”, ale także wzbogacony o nowe jednostki.

\begin{tabular}{|c|c|c|c|c|}
\hline Part 1 & Part 2 & Part 3 & Part 4 & Part 5 \\
\hline $\begin{array}{l}\text { Intro } \\
\text { Phrases } \\
\text { Travel } \\
\text { Restaurant } \\
\text { Family } \\
\text { Shopping } \\
\text { School } \\
\text { People } \\
\text { Checkpoint }\end{array}$ & $\begin{array}{l}\text { Greetings } \\
\text { Travel } 2 \\
\text { Schedule } \\
\text { People 2 } \\
\text { People } 3 \\
\text { School } 2 \\
\text { Family } 2 \\
\text { Work } \\
\text { Emotions } \\
\text { People 4 } \\
\text { Fashion } \\
\text { Travel } 3 \\
\text { Leisure } \\
\text { Activities } \\
\text { Preferences } \\
\text { Routines } \\
\text { Household } \\
\text { Restaurant } 2 \\
\text { Family } 3 \\
\text { Shopping } 2 \\
\text { Description } \\
\text { Recreation } \\
\text { Community } \\
\text { Phrases } 2 \\
\text { Community } 2 \\
\text { Routines } 2 \\
\text { Checkpoint }\end{array}$ & \begin{tabular}{|l} 
Activities 2 \\
Weather \\
Interest \\
Information \\
Description 2 \\
Travel 4 \\
Interest 2 \\
Groceries \\
Requests \\
Routines 3 \\
School 3 \\
Shopping 3 \\
Plans \\
Activities 3 \\
Household 2 \\
Community 3 \\
Directions \\
M emories \\
Farm \\
Recreation 2 \\
Vacation \\
Shopping 4 \\
Description 3 \\
Nature \\
Travel 5 \\
School 4 \\
History \\
Home \\
Checkpoint
\end{tabular} & $\begin{array}{l}\text { Food } \\
\text { Animals } \\
\text { Clothing } \\
\text { Present } 1 \\
\text { Food 2 } \\
\text { Family 4 } \\
\text { Household } 3 \\
\text { Occupation } \\
\text { Time } \\
\text { Adjectives } 1 \\
\text { Present 2 } \\
\text { Grammar } \\
\text { Adverbs } \\
\text { Objects } \\
\text { Places } \\
\text { People 5 } \\
\text { Numbers } \\
\text { Past } \\
\text { Present } 3 \\
\text { Verb Infinitive } 1 \\
\text { Ir Future } \\
\text { Countries } \\
\text { Adjectives 2 } \\
\text { Directions } 2 \\
\text { Education } \\
\text { Test out of } 49 \\
\text { Skills }\end{array}$ & $\begin{array}{l}\text { Vocabulary } 1 \\
\text { Participle } \\
\text { Feelings } \\
\text { Present Perfect } \\
\text { Past Perfect } \\
\text { Nature } 2 \\
\text { Vocabulary } 2 \\
\text { Verb Infinitive } 2 \\
\text { Sports } \\
\text { M edical } \\
\text { Gerund } \\
\text { Business } \\
\text { Communication } \\
\text { Spiritual } \\
\text { Future tense } \\
\text { Arts } \\
\text { Future Perfect } \\
\text { Politics } \\
\text { Subjunctive/Imperative } \\
\text { Science } \\
\text { Verb Modal } \\
\text { Verb Conditional } \\
\text { Past Imperfect } \\
\text { Subjunctive Past } \\
\text { Vocabulary } 3 \\
\text { Conditional Perfect } \\
\text { Checkpoint } \\
\text { Test out of } 75 \text { skills }\end{array}$ \\
\hline
\end{tabular}

Tabela 2: Przykładowy kurs języka hiszpańskiego dla użytkowników języka angielskiego - rozkład materiału ${ }^{11}$. źródło: https://www.duolingo.com/ [DW 16.01.2019].

Niezależnie od długości kursu, słownictwo i struktury oraz aspekty pragmatyczne w nim zawarte pozwalają użytkownikowi opanować dany język w stopniu umożliwiającym m.in. rozmowę o sprawach codziennych, komunikację w czasie podróżowania czy konwersowanie o swoich potrzebach i zainteresowaniach.

${ }^{11}$ Kurs ten przedstawiamy w: Aleksandrowska i Stanulewicz (2019: 128). 


\section{Typy ćwiczeń i informacja zwrotna/sposób korekty błędów}

Analizując cechy platformy i jej umiejscowienie w systemie metod uczenia się, należy stwierdzić, że opiera się ona na elementach metody gramatyczno-tłumaczeniowej oraz audiolingwalnej. Większość ćwiczeń polega bowiem na czytaniu i tłumaczeniu z języka wyjściowego (nauczania) na język docelowy (nauczany) krótkich tekstów, a jednocześnie sprawdzana jest umiejętność słuchania i powtarzania określonych form językowych. Kursy zawierają następujące typy ćwiczeń: tłumaczenie, tłumaczenie - ułożenie podanych wyrazów w odpowiednim porządku, dopasowanie słowa do obrazka, łączenie odpowiedników, wielokrotny wybór, wstawianie brakującego wyrazu, dyktando częściowe, dyktando całościowe oraz głośne odczytanie wyrazu, zwrotu lub zdania. Najczęściej stosowane typy ćwiczeń pokazują, że twórcy platformy Duolingo mają na celu przede wszystkim rozwijanie dwóch podsystemów języka gramatyki i słownictwa.

Chociaż nadmierne wykorzystanie dryli gramatycznych oraz tłumaczenia w nauce języka obcego jest krytykowane przez zwolenników metody komunikacyjnej, należy zauważyć, iż nie powinno się marginalizować i całkowicie rezygnować z wykorzystania języka ojczystego i technik pracy bilingwalnej, gdyż odgrywają one pozytywną rolę w procesie świadomego uczenia się języka obcego - zwłaszcza, jeżeli bierzemy pod uwagę ich wykorzystanie jako technik jedynie uzupełniających inne w procesie nauczania i uczenia się języka obcego. Gramatyczne dryle tłumaczeniowe, na przykład, sprzyjają opanowaniu struktur języka obcego (Scheffler, 2013), mogą bowiem „przyspieszyć akwizycję adekwatnych struktur w języku obcym przy wykorzystaniu mniejszej ilości energii poznawczej”, "uświadamiają uczniowi różnice i podobieństwa między językami", zmniejszając prawdopodobieństwo wystąpienia błędów interferencyjnych (Borecka, 2016: 168).

Oferowane przez platformę ćwiczenia oparte na wielokrotnym powtarzaniu materiału, choć pozbawione waloru poznawczego, są ważne w procesie nabywania wiedzy, bowiem „zakres i trwałość zapamiętanego przez uczniów materiału językowego jest do pewnego stopnia funkcją ilości i różnorodności sytuacji ćwiczebnych, w których materiał ten został przez nich użyty" (Szałek, 2004: 113).

Choć zadania zawarte w omawianej platformie odnoszą się do wszystkich umiejętności, ich rozwijanie nie udaje się w pełnym zakresie. Przykładowo, jeśli chodzi o doskonalenie umiejętności słuchania ze zrozumieniem, Duolingo „używa skomputeryzowanego systemu głosowego do wszystkich ćwiczeń ze słuchu, więc uczniowie nie są zaznajomieni z tym, jak naprawdę brzmi ten język. Głos jest suchy, nierytmiczny i brzmi jak komputer" (Mulya i Refnaldi, 2016: 294, tłum. O.A.). 
Jeżeli chodzi o ćwiczenia służące doskonaleniu sprawności mówienia, są one ograniczone do sprawdzania poprawności wymowy krótkich wyrażeń lub pojedynczych zdań. Oferowane ćwiczenia mają za zadanie sprawdzić poziom umiejętnosci uczącego się w ściśle określony sposób, bez przestrzeni dla kreatywności, tworzenia niekontrolowanych lub choćby dłuższych wypowiedzi ustnych, co zauważają także inni badacze analizujący platformę Duolingo (por. Savvani, 2019). Ponadto, w proponowanych ćwiczeniach, wyraźnie zauważalny jest brak znamion realnej komunikacji językowej, o której pisze Szałek (2004: 96) w kontekście potrzeby „ukomunikatywnienia” ćwiczeń językowych.

Kolejny istotny aspekt, który wymaga omówienia, to kwestia oceniania zadań rozwiązywanych przez uczącego się i uzyskiwania przez niego informacji zwrotnej. Szerszeń (2004: 19) stwierdza, że zauważalny jest postęp technologiczny w zakresie feedbacku, jaki uczeń otrzymuje od systemu platformy, na której się uczy. Dzięki coraz bardziej zaawansowanym rozwiązaniom technologicznym, wykonywane przez użytkownika zadania o charakterze zamkniętym generują automatycznie feedback, który zawiera zarówno poprawną odpowiedź, jak i czasem komentarz wyjaśniający jej wybór. Jak zauważa, Szerszeń (2014: 19), nadal niezbędna jest ręczna poprawa błędów przez nauczyciela w sytuacji ćwiczeń o charakterze otwartym, w których wielość i odmienność poprawnych odpowiedzi udzielonych przez uczącego się przekracza możliwości zaprogramowania automatycznego feedbacku.

Nie inaczej jest w przypadku platformy Duolingo, na której osoba ucząca się otrzymuje natychmiastową informację zwrotną na temat tego, w jakim stopniu opanowała daną jednostkę, a ewentualne błędy są poprawiane na bieżąco - w momencie udzielenia niepoprawnej odpowiedzi, system zaznacza błąd kolorem czerwonym i podaje prawidłową odpowiedź. Uczący się musi ją zapamiętać, aby bowiem ukończyć dany poziom, należy poprawnie odpowiedzieć na wszystkie pytania12.

Błędy ortograficzne w odpowiedziach uczącego się, takie jak użycie małych i wielkich liter, są zawsze korygowane, niemniej system nie zwraca uwagi na nieścisłości o charakterze interpunkcyjnym, jak na przykład brak przecinka, kropki lub znaku zapytania na końcu zdania.

\footnotetext{
${ }^{12} \mathrm{Gdy}$ więc system ponownie zada to samo pytanie, użytkownik platformy musi podać zapamiętaną i poprawioną wcześniej odpowiedź.
} 


\section{Wywiady}

\subsection{Uczestnicy badania i wybrane przez nich kursy językowe}

Do uzyskania informacji dotyczących korzystania z platformy Duolingo, a także opinii na jej temat, zastosowałyśmy ustrukturyzowany wywiad w formie pisemnej ${ }^{13}$. Kwestionariusz wywiadu zawierał 29 pytań.

Wywiady przeprowadziłyśmy w latach 2018 i 2019 z 32 użytkownikami Duolingo w wieku od 16 do 42 lat (23 kobietami 9 mężczyznami). Wśród uczestników badania znaleźli się uczniowie liceum ogólnokształcącego, studenci oraz osoby pracujące w sektorze edukacyjnym, marketingowym i wojskowym. Osoby te w chwili badania korzystały z platformy od 2 tygodni do 6 lat.

\begin{tabular}{|l|r|r|}
\hline Język & Liczba uczących się & $\%$ (N =32) \\
\hline hiszpański & 17 & 53,125 \\
\hline angielski & 10 & 31,250 \\
\hline francuski & 8 & 25,000 \\
\hline niemiecki & 8 & 25,000 \\
\hline włoski & 6 & 18,750 \\
\hline norweski & 4 & 12,500 \\
\hline rosyjski & 4 & 12,500 \\
\hline portugalski & 3 & 9,375 \\
\hline Szwedzki & 3 & 9,375 \\
\hline czeski & 1 & 3,125 \\
\hline esperanto & 1 & 3,125 \\
\hline hebrajski & 1 & 3,125 \\
\hline irlandzki & 1 & 3,125 \\
\hline jidysz & 1 & 3,125 \\
\hline koreański & 1 & 3,125 \\
\hline
\end{tabular}

Tabela 3: Popularność poszczególnych kursów językowych wśród uczestników badania. Opracowanie własne.

Najpopularniejszym językiem okazał się hiszpański - uczy się go za pomocą Duolingo 53\% uczestników badania. Na drugim miejscu uplasował się angielski (ok. 31\%), a na trzecim ex aequo francuski i niemiecki (po 25\%), zaś na kolejnych znalazły się włoski (prawie 19\%) oraz norweski i rosyjski (po 12,5\%). Trzy najpopularniejsze wśród uczestników badania języki są również najczęściej wybierane przez innych użytkowników platformy (Settles i in., 2018: 57). Tabela 3 prezentuje dane liczbowe i procentowe pozwalające ocenić popularność

${ }^{13}$ Badania pilotażowe przeprowadziłyśmy w grupie sześciu osób. Opisujemy je pokrótce w: Aleksandrowska i Stanulewicz (2019: 132-134). 
poszczególnych kursów językowych wśród uczestników wywiadów. Większość z nich (ok. 65\%) uczyła się dwóch, trzech, czterech lub pięciu języków na Duolingo w chwili badania lub - w niektórych przypadkach - w przeszłości (zob. tabela 4). Trzeba też tu dodać, że większość uczestników kontynuowała naukę co najmniej jednego języka przy pomocy platformy.

\begin{tabular}{|l|r|r|}
\hline Liczba języków & Liczba uczących się & $\%$ (N =32) \\
\hline 1 & 11 & 34,375 \\
\hline 2 & 10 & 31,250 \\
\hline 3 & 7 & 21,875 \\
\hline 4 & 3 & 9,375 \\
\hline 5 & 1 & 3,125 \\
\hline Ogółem & 32 & 100,000 \\
\hline
\end{tabular}

Tabela 4: Liczba kursów wybranych przez poszczególnych uczestników wywiadów. Opracowanie własne.

\subsection{Pytania zadane podczas wywiadów}

Wilczyńska i M ichońska-Stadnik (2010: 160) wyróżniają następujące przykładowe rodzaje pytań, które można zadać podczas wywiadu. Są to pytania biograficzne, pytania o zachowania i reakcje, pytania wymagające w odpowiedzi opinii lub oceny oraz pytania o odczucia lub o fakty.

Kwestionariusz naszego badania zawierał pytania biograficzne (np. o języki, których respondenci się uczą i czas ich nauki - zob. punkt 5.1 powyżej), pytania o zachowania (np. czy badani zdecydują się na naukę innych języków na platformie), pytania wymagające opinii bądź oceny (np. czy korzystanie z tej platformy spełnia ich oczekiwania), pytania o odczucia (np. czy woleliby uczyć się wybranego języka za pośrednictwem języka polskiego).

Poniżej skoncentrujemy się tylko na odpowiedziach udzielonych na wybrane pytania, które brzmiały następująco:

- Co sądzisz o tym, że nauka odbywa się na kursach Duolingo za pomocą języka angielskiego?

- Czy wolałabyś/-łbyś uczyć się języka obcego z użyciem języka polskiego, nie angielskiego?

- Jak oceniasz swoją naukę języka obcego na kursie Duolingo? Czego się nauczyłaś/-eś?

- Który aspekt znajomości języka obcego (docelowego) poprawiłaś/-eś w największym stopniu (słownictwo, gramatyka, wymowa, mówienie, pisanie, czytanie, słuchanie)? 
- Jakie znaczenie mają dla Ciebie elementy grywalizacji (rywalizacja, ranking, punkty, nagrody itp.)?

- Czy Twoim zdaniem, korzystając tylko z Duolingo można się nauczyć języka obcego tak, by swobodnie się nim porozumiewać, przynajmniej w sytuacjach codziennych i w podróży? Uzasadnij swoją odpowiedź.

- Jak można byłoby ulepszyć kurs? Jakich ćwiczeń Ci brakuje?

\section{Odpowiedzi udzielone przez uczestników wywiadów}

\subsection{Angielski jako język-pośrednik}

Jest oczywiste, że w nauce kolejnych języków korzysta się z wcześniejszych doświadczeń. Kucharczyk (2018: 119-120; za: Forgiel, 2019) omawia wielojęzyczne strategie poznawcze, metapoznawcze i społeczno-afektywne używane przy uczeniu się języków. W pierwszej grupie znalazły się m.in. strategie takie jak porównywanie języków pod różnymi względami, odwoływanie się do gramatyki znanych wcześniej języków, dostrzeganie internacjonalizmów czy wykorzystywanie umiejętności nabytych przy uczeniu się poprzednich języków. Druga grupa strategii związana jest z wcześniejszymi doświadczeniami w nauce języków i zawiera m.in. strategię określenia własnych mocnych i słabych stron. Trzecia grupa strategii związana jest m.in. z uświadomieniem sobie, że nauka języka wymaga czasu i wysiłku.

Jak zauważa Testa (2019: 8), „w klasie języka obcego (innego niż angielski) angielski L2 jest aktywnym składnikiem zarówno konstelacji językowej nauczyciela, jak i osób uczących się", a dzieje się tak ze względu na dominację angielszczyzny w komunikacji międzynarodowej. Jeżeli chodzi o język-pośrednik przy opracowywaniu kursów językowych (nie tylko tych oferowanych przez platformy internetowe) dla użytkowników władających różnymi językami ojczystymi, angielszczyzna - jako lingua franca - jest oczywistym wyborem. W wielu przypadkach osoby uczące się innych języków nawiązują do tego języka-pośrednika, stosując wyżej wspomniane strategie.

Większość respondentów w naszym badaniu nie ma problemów z uczeniem się innych języków za pośrednictwem angielskiego, chociaż niektórzy zauważają, że dla osób nieznających dostatecznie tego języka korzystanie z platformy jest niemożliwe lub utrudnione. Jedynie pięciu respondentów (co stanowi niecałe $16 \%$ ogółu osób badanych) wolałoby język ojczysty. Jedna z osób zwróciła uwagę na to, że gdy ktoś uczy się języka, w którym występuje kategoria przypadka, wyjaśnienia byłyby trafniejsze w języku polskim niż angielskim. Poniżej cytujemy trzy wybrane opinie. 
- "Jest to szansa, by przy okazji pozostać w kontakcie z językiem angielskim."

- Dla osób które nie posiadają dobrej znajomości języka angielskiego może to być sporę utrudnienie. Mnie osobiście nie przeszkadza jakoś bardzo."

- Myślę, że jest to zły pomysł."

\subsection{Samoocena nauki na Duolingo}

W procesie uczenia się języka obcego samoocena należy do najistotniejszych elementów pozwalających uczącemu się dokonać refleksji nad postępami i określić stopień satysfakcji z podejmowanych przez siebie wysiłków. Jak pisze M arkiewicz (2008: 342), „E-learning rozwija autonomię, wymagając od uczącego się zdecydowanie większej samokontroli i odpowiedzialności za własne kształcenie", dlatego też zasadnym wydaje się poprosić użytkowników platformy o dokonanie diagnozy swoich mocnych i słabych stron oraz o ocenę postępów w realizacji konkretnych celów językowych.

Na pytania, jak oceniają swoją naukę języka obcego (bądź języków obcych) przy pomocy Duolingo i czego się nauczyli, uczestnicy badania wskazali głównie na słownictwo (78\%), a na miejscu drugim znalazła się gramatyka (56\%). Tabela 5 przedstawia odpowiedzi na te pytania.

\begin{tabular}{|l|r|r|}
\hline $\begin{array}{l}\text { Komponent języka/sprawność } \\
\text { językowa/podstawy języka }\end{array}$ & Liczba uczestników & W odsetkach (N =32) \\
\hline słownictwo & 25 & 78,125 \\
\hline zwroty & 4 & 12,500 \\
\hline gramatyka & 18 & 56,250 \\
\hline słuchanie & 6 & 18,750 \\
\hline wymowa & 6 & 18,750 \\
\hline Czytanie & 3 & 9,375 \\
\hline pisanie & 2 & 6,250 \\
\hline podstawy języka & 3 & 9,375 \\
\hline
\end{tabular}

Tabela 5: Klasyfikacja odpowiedzi na pytania: Jak oceniasz swoja naukę języka obcego na kursie Duolingo? Czego się nauczyłaś/-eś? Który aspekt znajomości języka obcego (docelowego) poprawiłaśl-eś w największym stopniu (słownictwo, gramatyka, wymowa, mówienie, pisanie, czytanie, słuchanie)? Opracowanie własne.

Niektórzy użytkownicy kursów podali też, jak nauka na Duolingo została zweryfikowana w realnym życiu (zob. też punkt 6.4). Jedna z osób biorących udział w badaniu nauczyła się „podstawowych słówek i zwrotów, które na początku pobytu w Hiszpanii rzeczywiście okazały się dość pomocne". 


\subsection{Grywalizacja}

Elementy gier i zabaw mają zwykle korzystny wpływ na skuteczność nauczania/ uczenia się języka obcego, m.in. tworzą partnerską, życzliwą atmosferę nauki, wprowadzają element napięcia i rywalizacji, wzmacniają pozytywne nastawienie uczącego się do języka, którego się uczy, sprzyjają lepszej koncentracji ucznia, a także „pozwalają ukryć formalny, dydaktyczny cel ćwiczenia” (Szałek, 2004: 141). Jak zauważa Savvani (2019: 141-142), platforma Duolingo zaczerpnęła elementy z nurtu edukacji opartej o gry cyfrowe (ang. digital game-based language learning, DGBLL), bazując na interaktywności, wykorzystaniu bodźców wizualnych i dźwiękowych, zadaniow ości, według której użytkownik przechodzi przez pewne partie materiału (zadania), a także na informacji zwrotnej w postaci zachęcających odznak i innych nagród punktowych (tzw. lingots).

Opinie badanych przez nas osób dotyczące grywalizacji są podzielone szesnastu uczestników (50\%) uważa ją za motywującą, dla dziesięciu (32\%) jest bez znaczenia, zaś dwie osoby (6\%) nie miały zdania. Dla czterech respondentów (12,5\%) jest również nieważna, ale sądzą one, że może być przydatna dla innych uczących się języków obcych. Przytaczamy przykładowe odpowiedzi na pytanie Jakie znaczenie majq dla Ciebie elementy grywalizacji (rywalizacja, ranking, punkty, nagrody itp.)?:

- "Tak, dodatkowo motywują."

- "Motywujące do częstszej aktywności."

- "Nie mają znaczenia."

- "Dla mnie osobiście są bez większego znaczenia, jednak moi uczniowie którym polecałam aplikację (klasy 4-6 szkoły podstawowej) przywiązywali do tego dużo uwagi, często porównując wyniki."

W przyszłości, na podstawie większej liczby odpowiedzi, należałoby zbadać, czy ocena przydatności elementów grywalizacji jest powiązana z płcią i wiekiem użytkowników internetowych kursów językowych.

\subsection{Efektywność kursów i postulaty dotyczące ulepszenia kursów}

W literaturze przedmiotu znaleźć można wiele publikacji dotyczących efektywności platformy Duolingo (zob. Vesselinow i Grego, 2012; Krashen, 2014; de Castro, da Hora Macedo i Pinto Bastos, 2016; M ulya i Refnaldi, 2016; M unday, 2016). Przedstawiane przezautorów wyniki badań nie są jednoznaczne, gdyż wskazują oni zarówno na liczne zalety platformy, jak i obszary wymagające udoskonalenia. Vesselinovi Grego (2012: 2), na przykład, opublikowali raport o 8-tygodniowym procesie badań nad przydatnością platformy w nauce języka hiszpańskiego wśród 
jej użytkowników mieszkających w Stanach Zjednoczonych. Konkluzja odnośnie efektów była pozytywna - wyniki wskazały na poprawę ogólnych umiejętności językowych na poziomie ponad 90\%, przy czym największą skuteczność zauważyły osoby na początkowym poziomie znajomości języka. Krashen (2014) jednak dość krytycznie odniósł się do tego badania, podkreślając, iż Duolingo, tak jak wiele podobnych platform, opiera się na metodach świadomego uczenia się, które, jak twierdzi, nie rozwija prawdziwych kompetencji językowych. Przytacza przy tym dowody potwierdzające, że to podświadome przyswajanie języka przynosi większe efekty niż świadome, tradycyjne metody jego nauki.

Nasze badanie również miało na celu m.in. poznanie oceny użytkowników platformy dotyczącej efektywności nauki języka obcego za pomocą Duolingo. Jedno z pytań dotyczyło możliwości opanowania języka przy korzystaniu jedynie z Duolingo, tak by swobodnie się nim porozumiewać, przynajmniej w sytuacjach codziennych i w podróży. Tutaj opinie były również podzielone, a część badanych była niezdecydowana. Wśród odpowiedzi pozytywnych znalazły się następujące:

- „Myślę, że tak. Aplikacja oferuje nie tylko możliwość nauki słownictwa, ale też całych zwrotów z naciskiem na poprawność gramatyczną. Ucząc się pilnie z Duolingo można poradzić sobie w typowych sytuacjach, takich jak np. zapraszanie kogoś na spotkanie, kupowanie biletu na pociąg/autobus, „small talk”. M oże nie będzie to od razu zaawansowany poziom umiejętności, ale wydaje mi się, że taka osoba zostanie jak najbardziej zrozumiana."

- $\quad$ „Po nauce przez paręnaście minut dziennie przez jakieś 2 tygodnie byłam w stanie bez problemu przeprowadzić trochę sztywną, ale dość pełną rozmowę z nativem. Nie była ona do końca poprawna, ale potrafiłam się porozumieć i załatwić to, co chciałam. J eśli chodzi o prostą rozmowę (kupno biletu, zamówienie jedzenia, luźna konwersacja) aplikacja spełnia oczekiwania. Jeśli komuś zależy na bardziej zaawansowanym poznaniu języka - przydadzą się inne źródła."

- "Wszystko zależy od tego, jak wysoki ma być poziom komunikatywny. Proste porozumiewanie się z pewnością tak, gdyż to, co oferuje ta aplikacja jest wystarczające do takiej nauki, niestety jeśli ktoś oczekiwałby bardzo dobrej znajomości słów, czasów, wyrażeń to powinien szukać dodatkowych źródeł wiedzy."

W odpowiedziach negatywnych wyakcentowane zostały braki zauważone przez użytkowników platformy, a także potrzeba kontaktu z osobami mówiącymi danym językiem, np. 
- „Nie, jak wspomniałam, uważam, że brakuje ćwiczeń z gramatyki (same wytłumaczenie nie jest dla mnie wystarczające), słówka są zawsze podane, również aplikacja nie uczy zbytnio mówienia ani tworzenia własnych wypowiedzi pisemnych i ustnych (jest oparta na tłumaczeniach)."

- "Wydaje mi się, że nie, do tego trzeba mieć kontakt z żywym językiem, z osobą posługującą się danym językiem. To zupełnie coś innego ćwiczyć „na sucho" i porozumiewać się z obcokrajowcem."

Z pytaniem o efektywność kursów wiąże się pośrednio pytanie o ulepszenie kursów oferowanych przez Duolingo. Uczestnicy wywiadów podali następujące postulaty: wprowadzenie bardziej realistycznych przykładów zdań, uzupełnianie dialogów, pisanie dłuższych wypowiedzi, więcej ćwiczeń gramatycznych, wykorzystanie do ćwiczeń ze słuchu wypowiedzi rodzimego użytkownika języka zamiast generatora mowy, a także wprowadzenie większej liczby nowych słów.

\section{Wnioski}

Wyniki naszego badania wskazują na to, że respondenci są na ogół zadowoleni z korzystania z Duolingo. Jednak nie wszyscy z nich sądzą, że platforma internetowa może zaoferować kompletny kurs (jak pokazują odpowiedzi, można nauczyć się głównie słownictwa i gramatyki) - uważają oni, że może stanowić dobre uzupełnienie innych form nauki. Należy tu podkreślić, że prawie wszyscy badani wyrażają chęć kontynuacji nauki języków na Duolingo (np. „jest świetny, będę z niego korzystać dalej"), a większość z nich (ponad 60\%) chciałaby w przyszłości uczyć się kolejnych języków z Duolingo ${ }^{14}$.

Nauka języków obcych na kursach oferowanych przez platformy internetowe z pewnością wymaga dalszych badań. Należałoby szczególnie zainteresować się jej efektywnością nie tylko z perspektywy samooceny użytkowników. Dobrze byłoby też zbadać, w jakim stopniu kursy oferowane przez platformy internetowe mogą pomóc w samodzielnym opanowaniu języka, a także w jakim stopniu są przydatne jako uzupełnienie innych form nauczania (lekcji w szkole i lektoratów na uczelni oraz kursów w szkołach językowych) bądź jako kontynuacja nauki.

Ponadto warto byłoby dokładniej zająć się kwestią nauki jednego języka obcego za pośrednictwem innego języka obcego - czy i jak ułatwia to naukę tego pierwszego, a także czy użytkownicy platformy mają poczucie, że uczą się obu języków jednocześnie. Oczywiście należałoby wziąć pod uwagę specyfikę

\footnotetext{
${ }^{14}$ Respondenci wymieniali chiński, japoński, niderlandzki, szkocki gaelicki i walijski, a także kaszubski, którego platforma nie oferuje („Najbardziej chciałbym kaszubski, ale jeszcze nie ma").
} 
tych języków, dlatego też dobrze byłoby wyizolować na potrzeby takiego badania grupę np. Polaków uczących się języka hiszpańskiego (por. Orłowska 2011, 2015) lub innego języka za pośrednictwem języka angielskiego. Z pewnością ciekawe byłoby pozyskanie i zbadanie grupy osób uczących się jednego z języków nieindoeuropejskich i niekorzystających z innych form nauki.

W przyszłości warto byłoby również przeanalizować rodzaj i konstrukcję ćwiczeń proponowanych na platformie Duolingo w odniesieniu do rozmaitych kryteriów ich przygotowywania bądź ewaluacji omawianych w literaturze glottodydaktycznej (por. Pfeiffer, 1975, 2001; Komorowska, 2002). Wymagałoby to konfrontacji zestawu kryteriów stosowanych w ocenie poprawności i przydatności pedagogicznej tradycyjnego w formie materiału bądź ćwiczenia do nauki języka obcego z kryteriami charakterystycznymi dla materiałów interaktywnych, e-learningowych (por. Półtorak, 2007; Szerszeń, 2014).

\section{Podziękowania}

Serdecznie dziękujemy wszystkim uczestnikom naszego badania. Jesteśmy również wdzięczne Pani dr Justynie Pomierskiej i Panu Pawłowi Pomierskiemu za przeprowadzenie trzech wywiadów.

\section{BIBLIOGRAFIA}

Aleksandrowska O., Stanulewicz D. (2019), O korzystaniu zinternetowych platform do nauki języków (na przykładzie Duolingo), (w:) Grabowska M., Hinc J., Jarosz A., Mampe J. (red.), Translatoryka i glottodydaktyka - od badań do praktyki. Gdańsk: Wydawnictwo Uniwersytetu Gdańskiego, s. 119-135. Borecka V. (2016), Rola języka ojczystego w nauczaniu języków obcych - założenia teoretyczne oraz propozycje rozwiq̨zań metodycznych, (w:) Awramiuk E., Karolczuk M. (red.), Z problematyki kształcenia językowego, tom VI, Białystok: Wydawnictwo Uniwersytetu w Białymstoku, s. 149-170.

de Castro A. P., da Hora Macedo S., Pinto Bastos H. P. (2016), DUOLINGO: An experience in English teaching. "Journal of Educational \& Instructional Studies in the World, nr 6(4), s. 59-63. Online: https:// www.wjeis.org/Fil eUpload/ds217232/File/07.ana_paula_de_castro.pdf/ [DW 02.02.2020]. Forgiel I. (2019), Jak uczyć jednego języka obcego z wykorzystaniem drugiego. "J ęzyki Obce w Szkole", nr 5, s. 14-17.

Komorowska H. (2002), Metodyka nauczania języków obcych. Warszawa: Fraszka Edukacyjna.

Krajka J. (2007), English Language Teaching in the Internet-Assisted Environment. Lublin: Wydawnictwo Uniwersytetu Marii Curie-Skłodowskiej. 
Krajka J. (2012), The Language Teacher in the Digital Age - Towards a Systematic Approach to Digital Teacher Development. Lublin: Wydawnictwo Uniwersytetu M arii Curie-Skłodowskiej.

Krashen S. (2014), Does Duolingo "trump" university-level language learning, (w:) International J ournal of Foreign Language Teaching 9(1), s. 13-15. Online: https:// www.sdkrashen.com/ content/articles/krashen-does-duo lingo-trump.pdf/ [DW 22.01.2020].

Kucharczyk R. (2018), Nauczanie języków obcych a dydaktyka wielojęzyczności

(na przykładzie francuskiego jako drugiego języka obcego). Lublin: Wydawnictwo Werset.

Maciaszczyk S. (2019), The Design and Implementation of Blended Language Courses in Tertiary Education. Berlin: Peter Lang.

Marczak M., Krajka J. (red.) (2016), CALL for Openness. Frankfurt am Main: Peter Lang.

Markiewicz W. (2008), E-learning jako narzędzie rozwijania autonomii ucznia, (w:) Pawlak M. (red.), Autonomia w nauce języka obcego - co osiągnęliśmy i dokąd zmierzamy? Poznań - Kalisz - Konin: Wydawnictwo UAM i PWSZ w Koninie, s. 335-343.

Mulya A., Refnaldi R. (2016), Using school.duolingo.com as an alternative e-learning at senior high school for teaching and learning English online. "Journal of English Language Teaching", nr 5(1). Series D, s. 287-295. Online: https:// ejournal.unp.ac.id/index.php/jelt/article/view/7315/5746 [DW 09.01.2020].

M unday P. (2015), The case for using DUOLINGO as part of the language classroom experience. „RIED: Revista Iberoamericana de Educación a Distancia", nr 19, s. 83-101. Online: https:// www.researchgate.net/ publicatio n/284517271_The_case_for_using_DUOLINGO_as_part_of_the_langua ge_classroom_experience [DW 09.01.2020].

Orłowska N. (2011), La norma linguística y la enseñanza del español como lengua extranjera: influencia de la primera lengua extranjera (L2) en el proceso de adquisición de la siguiente lengua extranjera (L3), (w:) Waluchde la Torre E. (red.), La norma lingüística del español. Varsovia: M useo de Historia del Movimiento Popular Polaco, s. 247-252.

Orłowska N. (2015), Jak łatwiej nauczyć się kolejnego języka. Wpływ języka ojczystego i pierwszego języka obcego (L2) na proces poznawania kolejnego języka (L3). Saarbrücken: Wydawnictwo Bezkresy.

Pfeiffer W. (1975), Teoretyczne podstawy preparacji materiałów glottodydaktycznych. Poznań: Wydawnictwo Naukowe UAM .

Pfeiffer W. (2001), Nauka języków obcych. Od praktyki do praktyki. Poznań: Wagros. Pitura J., Sauro S. (red.) (2018), CALL for M obility. Frankfurt am M ain: Peter Lang. 
Półtorak E. (2007), Propozycje kryteriów oceny ćwiczeń interaktywnych, (w:) Jodłowiec M., Niżegorodcew A. (red.), Dydaktyka języków obcych na początku XXI wieku. Kraków: Wydawnictwo Uniwersytetu Jagiellońskiego, s. 125-134.

Savvani S. (2019), State-of-the-Art Duolingo: Features and Applications, (w:) Auer M. E., Tsiatsos T. (red.), The Challenges of the Digital Transformation in Education: Proceedings of the 21st International Conference on Interactive Collaborative Learning (ICL 2018). Volume 2. Springer International Publishing, s. 139-147.

Scheffler P. (2013), Gramatyczne dryle tłumaczeniowe w nauczaniu języka angielskiego. "J ęzyki Obce w Szkole", nr 1, s. 82-87.

Settles B. i in. (2018), Second language acquisition modeling, (w:) Tetreault J. R., Kochmar E., Leacock C., Yannakoudakis H. (red.), Proceedings of the Thirteenth Workshop on Innovative Use of NLP for Building Educational Applications. New Orleans: Association for Computational Linguistics. Online: https://ai.duolingo.com/papers/settles.slam18.pdf [DW 12.01.2019].

Szałek M . (2004), Jak motywować uczniów do nauki języka obcego. M otywacja w teorii i praktyce. Poznań: Wagros.

Szerszeń P. (2014), Platformy (glotto)dydaktyczne. Ich implementacja w uczeniu specjalistycznych języków obcych. Warszawa: Wydawnictwo Naukowe Instytutu Kulturologii i Lingwistyki Antropocentrycznej Uniwersytetu Warszawskiego.

Testa M. (2019), Wykorzystanie innego języka w nauce języka tercjalnego. „Języki Obce w Szkole", nr 5, s. 7-13.

Turula A., Chojnacka M . (red.) (2015), CALL for Bridges between School and Academia. Frankfurt am Main: Peter Lang.

Turula A., M ikołajewska B., Stanulewicz D. (red.) (2015), Insights into Technology Enhanced Language Pedagogy. Frankfurt am Main: Peter Lang.

Wilczyńska W., M ichońska-Stadnik A. (2010), Metodologia badań w glottodydaktyce. Wprowadzenie. Kraków: Avalon, Flair.

Vesselinov R., Grego J. (2012), Duolingo effectiveness study: Final report. Online: http://static.duolingo.com/s3/DuolingoReport_Final.pdf [DW 13.02.2020].

Zapaśnik H. (2018), Na Duolingo języka obcego uczy się Bill Gates, najbogatszy człowiek świata. (w:) Outride.rs, 18.10.2018. Online: https:// outride.rs/ pl/na-duolingo-jezyka-obcego-uczy-sie-bill-gates-najbogatszy-czlowiek -swiata/ [DW 02.03.2019].

\section{NETOGRAFIA}

Duolingo language forums, https://forum.duolingo.com/ [DW 29.12.2019]. 
Duolingo podcast, https://podcast.duolingo.com/ [DW 29.12.2019].

Duolingo research, https:// research.duolingo.com/ [DW 29.12.2019].

Duolingo stories, https://stories.duolingo.com/ [DW 29.12.2019].

M anifesto, https:// www.duolingo.com/info [DW 16.01.2019].io00000okjiiiii Polish-English translation, https://www.duolingo.com/dictionary/pl [DW 29.12.2019]. Tinycards, https://tinycards.duolingo.com/ [DW 29.12.2019]. 